\section{Alumina Recovery from Industrial Waste: Study on the Thermal, Tensile and Wear Properties of Polypropylene/Alumina Nanocomposites}

By: Sufian, AS (Sufian, Anis Sofia) ${ }^{[1]}$; Samat, N (Samat, Noorasikin) ${ }^{[2]}$; Sulaiman, MYM (Sulaiman, Meor Yusoff Meor) ${ }^{[3]}$; Paulus, W (Paulus, Wilfred) ${ }^{[3]}$

View Web of Science ResearcherID and ORCID

INTERNATIONAL JOURNAL OF PRECISION ENGINEERING AND MANUFACTURING-GREEN TECHNOLOGY

Volume: 7 Issue: 1 Pages: 163-172

DOI: $10.1007 / \mathrm{s} 40684-019-00135-z$

Published: JAN 2020

Document Type: Article

View Journal Impact

\section{Abstract}

The investigation on the influences of alumina (Al203) particles in nano-sized retrieved from Aluminium ( $\mathrm{Al}$ ) dross was conducted on the tensile, thermal and wear properties of polypropylene (PP) composites. The thermal decomposition method was used to synthesise the micro alpha-Al2O3 particles from Al-dross, was followed by the wet-milling method to produce the nano alpha-Al203. The PP composites (nano and micro alpha-Al2O3 particles) were prepared via melt compounding followed by compression molding. The coupling agent was also added to facilitate the particle dispersion. The tensile tests showed the maximum tensile strength and Young's modulus of both composites to be corresponding to the samples containing $5 \mathrm{wt} \%$ of alpha-Al2O3. The superiority of nano alpha-Al2O3 on improving the property of PP had also been evident in the abrasive wear performance. A small amount of alpha-Al2O3 had been adequate in enhancing the thermal stability of PP than that of neat PP. The study on tensile and worn surface with SEM had revealed better adhesion and interaction between the filler and matrix in composites that were treated with coupling agent. The recovery of nano alpha-Al203 particles from Al-dross potentially decreases the quantity of harmful solid waste and can be an effective alternative filler for thermoplastics.

\section{Keywords}

Author Keywords: Alumina nanoparticle; Reinforcement; Thermal; Mechanical property; Wear; Waste KeyWords Plus: MECHANICAL-PROPERTIES; FILLERS

\section{Author Information}

\section{Reprint Address:}

International Islamic University Malaysia Int Islamic Univ Malaysia, Dept Mfg \& Mat Engn, Jalan Gombak, Kuala Lumpur 53100, Malaysia.

Corresponding Address: Samat, $\mathrm{N}$ (corresponding author)

+ Int Islamic Univ Malaysia, Dept Mfg \& Mat Engn, Jalan Gombak, Kuala Lumpur 53100, Malaysia Addresses:

+ [1] Univ Malaysia Perlis, Sch Mat Engn, Kompleks Pusat Pengajian Jejawi 2, Arau 02600, Perlis, Malaysia

+ [2 ] Int Islamic Univ Malaysia, Dept Mfg \& Mat Engn, Jalan Gombak, Kuala Lumpur 53100, Malaysia

+ [3 ] Agensi Nuklear Malaysia, Ind Technol Grp, Mat Technol Grp, Kajang 43000, Selangor, Malaysia

E-mail Addresses: noorasikin@iium.edu.my

\section{Publisher}

KOREAN SOC PRECISION ENG, RM 306, KWANGMYUNG BLDG, 5-4 NONHYUN-DONG, KANGNAM-GU, SEOUL, 135-010, SOUTH KOREA

\section{Journal Information}

Impact Factor: Journal Citation Reports

\section{Categories / Classification}

Research Areas: Science \& Technology - Other Topics; Engineering

Web of Science Categories: Green \& Sustainable Science \& Technology; Engineering, Manufacturing; Engineering, Mechanical

\section{Citation Network}

In Web of Science Core Collection

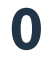

Times Cited

Create Citation Alert

\section{3}

Cited References

View Related Records

(i) New! You may also like ... ${ }^{\text {BETA }}$

Electrical and dielectric properties of polyaniline-Al2O3 nanocomposites derived from various $\mathrm{Al} 2 \mathrm{O} 3$ nanostructures.

JOURNAL OF MATERIALS CHEMISTRY (2011)

Processing-property relationships of polycarbonate/graphene composites. POLYMER (2009)

Electro-oxidation of some non-steroida anti-inflammatory drugs on an alumina nanoparticle-modified glassy carbon electrode.

TURKISH JOURNAL OF CHEMISTRY (2010)

Studies on POM/graphite/Ekonol composites. BULLETIN OF MATERIALS SCIENCE (2003)

Poly(lactic acid)/halloysite nanotube nanocomposites with high impact strength and water barrier properties. JOURNAL OF COMPOSITE MATERIALS (2016)

View all suggestions

\section{Use in Web of Science}

Web of Science Usage Count

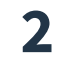

Last 180 Days $\quad$ Since 2013

Learn more

This record is from

Web of Science Core Collection

-Science Citation Index Expanded

Suggest a correction

If you would like to improve the quality of the data in this record, please suggest a correction. 


\section{Cited References: 23}

1. Evaluation of the mechanical properties of polypropylene-aluminum-dross composite

Times Cited: 3 By: Adeosun, S. O.; Usman, M. A.; Ayool, W.A.; et al.

ISRN Polym. Sci Volume: 2012 Pages: 1-6 Published: 2012

[Show additional data]

2. Effect of Dispersants on Microstructures of Nano Alpha Alumina Developed from Aluminium Dross Waste

Times Cited: 1

By: Anis Sofia, S.; Samat, N.; Sulaiman Meor Yusoff, M.

Advanced Materials Research Volume: 1115 Pages: 378-81 Published: 2015

3. Study of the wear rate of some polymer materials in different conditions

Times Cited: 1

By: Bushra, HM.

Journal of Engineering Technology Volume: 28 Issue: 16 Pages: 5165-5170 Published: 2010

4. Ecofriendly Treatment of Aloe Vera Fibers for PLA Based Green Composites

Times Cited: 14 By: Chaitanya, Saurabh; Singh, Inderdeep

INTERNATIONAL JOURNAL OF PRECISION ENGINEERING AND MANUFACTURING-GREEN TECHNOLOGY Volume: 5 Issue: 1 Pages: 143-

150 Published: JAN 2018

5. Development of aluminum dross-based material for engineering application

By: Dai, C.

THESIS Published: 2012

PhD Dissertation

Publisher: Worcester Polytechnic Institute.

6. Effect of Maleated Anhydride on Mechanical Properties of Rice Husk Filler Reinforced PLA Matrix Polymer Composite

By: Hamdan, M. H. M.; Siregar, J. P.; Rejab, M. R. M.; et al.

INTERNATIONAL JOURNAL OF PRECISION ENGINEERING AND MANUFACTURING-GREEN TECHNOLOGY Volume: 6 Issue: 1 Pages: $113-$

124 Published: JAN 2019

7. A review of recent developments in flammability of polymer nanocomposites

Times Cited: 48

By: Idumah, Christopher Igwe; Hassan, Azman; Affam, Augustine Chioma

REVIEWS IN CHEMICAL ENGINEERING Volume: 31 Issue: 2 Pages: 149-177 Published: APR 2015

8. Effect of alumina nanoparticle addition on the mechanical and wear behaviour of reinforced acrylonitrile butadiene styrene polymer

By: Kakde, P; Paul, SN.

International Journal of Advanced Research in Science, Engineering and Technology Volume: 5 Issue: 6 Pages: 185-192 Published: 2014

9. Characterizing the physical and chemical properties of aluminum dross

Times Cited: 60

By: Manfredi, O; Wuth, W; Bohlinger,

JOM-JOURNAL OF THE MINERALS METALS \& MATERIALS SOCIETY Volume: 49 Issue: 11 Pages: 48-51 Published: NOV 1997

10. Effect of particle size on the wear resistance of alumina-filled PTFE micro- and nanocomposites

Times Cited: 94

By: Mcelwain, Steven E.; Blanchet, Thierry A.; Schadler, Linda S.; et al.

TRIBOLOGY TRANSACTIONS Volume: 51 Issue: 3 Pages: 247-253 Published: 2008

11. Effect of Milling Time and Dispersant on Microstructures of Alpha Alumina Nanopowder Synthesized from Aluminium Dross Waste

By: Meor, Yusof M. S.; Masliana, M.; Wilfred, P.; et al.

NANOMATERIALS: SYNTHESIS AND CHARACTERIZATION Book Series: Advanced Materials Research Volume: 364 Pages: $372-376$

Published: 2012

12. Effects of nano alpha-Al203 fillers and dispersant on thermal and dynamic mechanical properties of polypropylene/nano Times Cited: 11 alpha-Al203 composite

By: Mirjalili, F.; Chuah, L.; Khalid, M.; et al.

JOURNAL OF THERMOPLASTIC COMPOSITE MATERIALS Volume: 25 Issue: 4 Pages: 453-467 Published: JUN 2012

13. Mechanical and Morphological Properties of Polypropylene/Nano alpha-Al203 Composites

Times Cited: 21 By: Mirjalili, F.; Chuah, L.; Salahi, E.

SCIENTIFIC WORLD JOURNAL Article Number: 718765 Published: 2014

14. Composites of polypropylene melt blended with synthesized silica nanoparticles

Times Cited: 58 By: Palza, H.; Vergara, R.; Zapata, P. 
15. XRD and SEM characterization of different alumina crystalline forms from aluminium white dross waste

By: Paulus, W.; Meor Yusoff, M.S.; Muslim, M.; et al.

P IMTEC 2010 KUCH Published: 201

[Show additional data]

16. A comparative study of the effect of different rigid fillers on the fracture and failure behavior of polypropylene based

Times Cited: 32 composites

By: Perez, E.; Alvarez, V.; Perez, C. J.; et al.

COMPOSITES PART B-ENGINEERING Volume: 52 Pages: 72-83 Published: SEP 2013

17. Alumina

Times Cited: 7

By: Piconi, C

Comprehensive Biomaterials Volume: 1 Pages: 73-94 Published: 2011

Publisher: Elsevier, Amsterdam

[Show additional data]

18. Extraction of value added product from waste aluminium dross

By: Rajeshkumar, L; Pranab, D.

International Journal of Engineering Research in Mechanical and Civil Engineering Volume: 2 Issue: 4 Pages: 54-58 Published: 2017

19. Tensile and impact properties of polypropylene/microcrystalline cellulose treated with different coupling agents

By: Samat, N.; Marini, C. D. Maritho, M. A.; et al.

COMPOSITEINTERFACES Volume: 20 Issue: 7 Special Issue: SI Pages: 497-506 Published: OCT 12013

20. Evaluation of Waste from Aluminum Industry as Filler in Polypropylene Composites

Times Cited: 4

By: Samat, N.; Sabaruddin, F. A.; Yusoff, M. S. Meor; et al.

JOM Volume: 69 Issue: 4 Pages: 790-795 Published: APR 2017

21. Enhanced interfacial adhesion of polypropylene and waste wood from roadside trees composite materials

By: Sohn, Joo Seong; Cha, Sung Woon

INTERNATIONAL JOURNAL OF PRECISION ENGINEERING AND MANUFACTURING Volume: 16 Issue: 11 Pages: $2389-2393$ Published: OCT 2015

22. Mechanisms leading to improved mechanical performance in nanoscale alumina filled epoxy

By: Zhao, Su; Schadler, Linda S.; Duncan, Renee; et al.

COMPOSITES SCIENCE AND TECHNOLOGY Volume: 68 Issue: 14 Special Issue: SI Pages: 2965-2975 Published: NOV 2008

23. Mechanical properties and failure modes of recycled polypropylene/microcrystalline cellulose composites

By: Zulkifli, N. Izzati; Samat, N.; Anuar, H.; et al.

Times Cited: 61

MATERIALS \& DESIGN Volume: 69 Pages: 114-123 Published: MAR 152015

Showing 23 of $23 \quad$ View All in Cited References page 